\title{
Financing the Urban Development in Germany
}

\author{
Evgenia Atamas ${ }^{1, *}$ Evgenia Arumova ${ }^{1, a}$
}

\author{
${ }^{1}$ Kuban State University, Krasnodar, Russia \\ ${ }^{a}$ Email: arumova.kubsu@mail.ru \\ *Corresponding author. Email: eatamas@bk.ru
}

\begin{abstract}
This article considers the system of financing of urban development in Germany. Today, the most pressing issue is the study of factors contributing to the sustainable urban development. One such factor is urban development financing. Urbanisation processes which are taking place today have exacerbated the problems of modern cities. Problems arising from urban growth dynamics, such as transport and communications, environmental and other issues, are coming to the fore. The authors of the article consider the main programmes for financing cluster structures in Germany. The authors have established that the cluster policy is a real tool for promoting innovative technologies and is a promising approach for improving regional innovation opportunities.
\end{abstract}

Keywords: green economy, green finance, sustainable development, financing, city, urban development

\section{INTRODUCTION}

Back in the last century, Russian economist I.V. Vernadsky wrote: "Each area has its own ideal, each country has its own forms of perfection, alien to others, under different conditions of the standing area. This is the main reason for the difference that exists in the economic, social and political situation". The city is one of the greatest and most complex creations of man. "The city is not homes, but people". These 'Shakespearean' words are the fundamental philosophical idea of the city as a community of people.

Today, the urban lifestyle is characterised by such features as overcrowding, motorisation, environmental problems, etc. Housing and urban renewal are also one of the most significant problems at the present time. Simultaneously with these problems, it is difficult to resolve the issue of housing stock renovation. And all this is happening against the background of the city budget crisis and the general unfavourable situation in the country. For a city to develop sustainably, it is necessary to create a favourable urban environment.

\section{CITIES AS FOCAL POINTS FOR} \section{DEVELOPMENT}

Cities in Germany are diverse in terms of their structure, history, location and urban development features. The settling structure in Germany is historic and much decentralised in terms of political administration. Germany has lots of diverse cities and communities. Of about 4,500 communities and community clusters, $30 \%$ are cities and $70 \%$ are rural communities. There are only 78 major cities in
Germany and most of them are located in West Germany (only 12 in East Germany).

In the Federal Republic of Germany, the Federal Institute for Building, Urban and Regional Studies (BBSR) which is subordinate to the Federal Office for Building and Regional Planning (BBR), is actively involved in the policy of state, regional and city authorities regarding trends in urban development.

In Germany, 16 federal states have initiated a number of measures to support the development of effective clusters. These measures take into account the individuality of strong regions in technology, business or innovation, and are organised around existing structures specific to the region.

A system of cluster support and development has been in place in Germany for twenty years, both at the state and federal state levels. The objective of the cluster policy is to strengthen cooperation between science and industry in the regions.

"Table I" provides an overall description of the cluster support programmes at the federal state level in Germany. 
TABLE I. PROGRAMMES TO SUPPORT CLUSTER INITIATIVES AT THE FEDERAL STATE LEVEL [1]

\begin{tabular}{|c|l|}
\hline Federal state & \multicolumn{1}{|c|}{ Support from authorities } \\
\hline Bavaria (Munich) & Clusteroffensive (cluster initiatives) \\
\hline Baden - Wurtenberg (Stuttgart) & Regionaler Clusterwettbewerb (cluster competitive ability development) \\
\hline Brandenburg (Potsdam) & Innovationsstrategie Berlin (innovative strategy) \\
\hline Hessen (Wiesbaden) & Clusterorientierung der Regionalpolitik Brandenburg (cluster-based policy) \\
\hline Mecklenburg - Western Pomerania (Schwerin) & Förderung regionaler Netzwerke (assistance to regional network) \\
\cline { 1 - 2 } Saarland (Saarbrucken) & Innovationsstrategie (innovative strategy) \\
\cline { 1 - 2 } Saxony (Dresden) & Landesexzellenzwettbewerb (state supporting) \\
\cline { 1 - 2 } North Rhine-Westphalia (Dusseldorf) & $\begin{array}{l}\text { RegioCluster (development of internationally competitive clusters in } \\
\text { relevant areas) }\end{array}$ \\
\cline { 1 - 2 } Saxony-Anhalt (Magdeburg) & Cluster Prozess der Region Mitteldeutschland (cluster processes in region) \\
\cline { 1 - 2 } Thuringia (Erfurt) & Clusterpolitik Schleswig-Holstein (cluster policy ) \\
\cline { 1 - 2 } Schlewig-Holstein (Kiel) & \multicolumn{1}{|r}{} \\
\cline { 1 - 2 }
\end{tabular}

Within the Federal Government, the Federal Ministry of Economics and Technology and the Federal Ministry of Education and Research, financing has been secured to develop effective cluster structures at the national level. This is the basis for intensive cooperation and knowledge transfer between science and business.

\section{PROgRAMMES FOR FINANCING CLUSTER STRUCTURES}

The main areas of government activity include developing cluster structures, improving the quality of cluster management, ensuring support for innovative concepts, research and development, and financing any other projects aimed at implementing the cluster's competitive strategies.

Federal Ministry of Economics and Technology: "Go-cluster: Exzellent vernetzt!" programme (Cluster: ready-made connections) provides incentives for better cluster management and shapes cluster policy with the aim of transforming German clusters into highly efficient international clusters[2]. This initiative supports innovative services and increases the international visibility of German innovation clusters. Participants in the cluster initiative can receive financing through participation in this programme.

Federal Ministry of Education and Research: The objective of "Spitzencluster-Wettbewerb - Mehr Innovation. Mehr Wachstum" programme (The more innovations, the more growth) is the support of high technology clusters. The financing provided under the programme supports cluster participants in the implementation of their projects and also contributes to their advancement on an international level in the long term [3]. The basis for sustainable development of the territory is the participation of concerned parties (business, universities, scientific organisations) in the development of innovative potential through the creation and development of cluster structures.

'Unternehmen Region - Die BMBFInnovationsinitiative für die Neuen Länder' Programme (Regional business - initiative of the Ministry of Education and Scientific Innovations - Innovations for new German federal states). The main objective of this programme is to create and develop technology, science and business in the regions of former East Germany [4]. The Programme includes the following projects: InnoRegio (developing innovation potential by supporting regional initiatives through cooperation), Innovative regionale Wachstumskerne (regional growth points, promoting alliances between companies, universities and research institutes), Zentren für Innovationskompetenz (innovation development centres), Innovationsforen (innovation forum), InnoProfile. This programme is aimed at developing regional business clusters for innovation, economic growth and employment in East Germany.

Thus, the alignment of modern territorial development is increasingly aimed at strengthening existing regional resources.

As the most important tool for national urban development policy based on the "For City and Urbanism" (Für Stadt und Urbanität) series project, the national urban development project "Nationalen Stadtentwicklungspolitik" has been developed in Germany. This project consists of several programmes that reflect the current and innovative development of the city area. The existing programmes reflect not only the legal, economic and management policy of city authorities for the development of the area, but also the level of citizen involvement in the city development system. 
The Project includes the following urban development programmes:

- Bürger für ihre Stadt aktivieren Zivilgesellschaft (urban society);

- Chancen schaffen und Zusammenhalt bewahren - Soziale Stadt (social city) - city policy should be aimed at taking care of people;

- Innovative Stadt - Motor der wirtschaftlichen Entwicklung (innovative city - economic development). Within the urban economy, one can distinguish the link between innovation system, production and marketing. The national urban development policy helps to ensure that both existing and future economic problems are solved at the city level by using new technologies;

- Städte besser gestalten - Baukultur (spatial development-architecture);

- Die Stadt von morgen bauen - Klimaschutz und globale Verantwortung (city of future environmental development);

- Die Zukunft der Stadt ist die Region Regionalisierung (the future of the city is the development of regions). The national urban policy aims at creating new practical forms of cooperation and regional partnerships in urban development ("Table II").

TABLE II. IMPLEMENTATION OF THE NATIONAL URBAN DEVELOPMENT PROJECT [5]

\begin{tabular}{|c|c|c|c|c|c|}
\hline & \multicolumn{5}{|c|}{ National urban development project “Nationalen Stadtentwicklungspolitik” } \\
\hline $\begin{array}{l}\text { Realization } \\
\text { (financing) }\end{array}$ & $\begin{array}{l}\text { Bürger für } \\
\text { ihre Stadt } \\
\text { aktivieren - } \\
\text { Zivilgesellsch } \\
\text { aft (urban } \\
\text { society) }\end{array}$ & $\begin{array}{l}\text { Soziale } \\
\text { Stadt }\end{array}$ & $\begin{array}{l}\text { Städte besser } \\
\text { gestalten - } \\
\text { Baukultur } \\
\text { (spatial } \\
\text { development- } \\
\text { architecture) }\end{array}$ & $\begin{array}{lr}\text { Die Stadt } & \text { von } \\
\text { morgen bauen } & - \\
\text { Klimaschutz } & \text { und } \\
\text { globale } & \\
\text { Verantwortung } & \text { (city } \\
\text { of future } & - \\
\text { environmental } & \\
\text { development) } & \end{array}$ & $\begin{array}{l}\text { Die Zukunft der } \\
\text { Stadt ist die } \\
\text { Region } \\
\text { Regionalisierung } \\
\text { (the future of the } \\
\text { city is the } \\
\text { development of } \\
\text { regions). }\end{array}$ \\
\hline City financing & $\begin{array}{l}\text { Dessau, } \\
\text { Leipzig, } \\
\text { Halle, } \\
\text { Hannover }\end{array}$ & $\begin{array}{l}\text { Hamburg, } \\
\text { Munich } \\
\text { Stuttgart, } \\
\text { Saarbrücken } \\
\text {, Cologne } \\
\end{array}$ & $\begin{array}{l}\text { Munich, } \\
\text { Darmstadt, } \\
\text { Fulda, } \\
\text { Görlitz }\end{array}$ & $\begin{array}{l}\text { Stuttgart, Karlsruhe, } \\
\text { Bremen, }\end{array}$ & $\begin{array}{l}\text { Göttingen, Guben, } \\
\text { Bremen, } \\
\text { Nuremberg, } \\
\text { Leipzig }\end{array}$ \\
\hline Co-financing & $\begin{array}{l}\text { Dessau } \\
\text { Halle }\end{array}$ & & & & $\begin{array}{ll}\text { Bremen } & - \\
\text { Nuremberg } & - \\
\text { Leipzig; } & \\
\text { Braunschweig } & - \\
\text { Göttingen } & - \\
\text { Hannover } & \\
\end{array}$ \\
\hline $\begin{array}{c}\text { Regional } \\
\text { Financing }\end{array}$ & & & $\begin{array}{l}\text { Cologne- } \\
\text { Bonn; } \\
\text { Hannover }\end{array}$ & $\begin{array}{l}\text { Speyer }- \text { Neustadt } \\
\text { Südpfalz }\end{array}$ & \\
\hline $\begin{array}{c}\text { Federal } \\
\text { Financing }\end{array}$ & $\begin{array}{l}\text { Berlin, } \\
\text { Hannover }\end{array}$ & Darmstadt & $\begin{array}{l}\text { Darmstadt, } \\
\text { Fulda, Bottrop }\end{array}$ & Pritzwalk -Witt stock & \\
\hline
\end{tabular}

For example, according to the "Social City" programme, the social development objectives of cities are diverse: in addition to improving housing stock, the quality and attractiveness of households, the main objective is still to promote integration and social cohesion. In this connection, financing for education, employment and integration of migrants is being provided in conjunction with the "City Investment" programme. For the period from 1999 to 2009, more than 350 communities and about 570 cities/towns participated in the programme.

The Federal Government finances about one third of the entire programme, which amounts to around EUR 890 million. Taking into account the additional financing from the federal states and communities that participate in the same volume, the amount for the programme was EUR 2.7 billion in 2009. In 2010, an additional EUR 95 million of federal funds were provided to the programme.

The amount of money that can be used for pilot projects complements youth and education policies that support the integration of immigrants and contribute to the local economy.

Combination with other programmes is a key element of the integrated urban development programme. Improving opportunities for young and unemployed people is an important objective. Since 2008, the "Social City" programme has been additionally financed by the European Social Fund (ESF) and the Federal Ministry of Transport, Building and City Services. Together with the ESF Federal 
Programme "Social City - Education, Business and Work in the Neighbourhood (BIWAQ)", measures to improve the quality of staff education and training, promote employment and strengthen the local economy are supported.

The main partners of the federal authorities are local housing owner associations, educational institutions, charity organisations, churches, foundations and unions.

Thus, the federal government makes an important and effective contribution to the strengthening of social cohesion and economic efficiency and employment opportunities in cities and towns.

The financing of urban development in Germany is possible not only through programmes offered by the state, but also through funds such as: JESSICA (Joint European Support for Sustainable Investment in City Areas), JASPERS (Joint Assistance to Support Projects in European Regions) and JEREMIE (Joint European Resources for Micro to Medium Enterprises).

JESSICA (Joint European Support for Sustainable Investment in City Areas) is an initiative developed by the European Commission and the European Investment Development Bank (DAC) in cooperation with the European Council. According to the new procedures, EU Member States are now able to use the resources of this fund in the form of EU grants, the socalled structural funds, with which it is possible to invest in projects that form part of an integrated urban sustainable development plan [6].

JASPERS (Joint Assistance to Support Projects in European Regions) - joint assistance in support of projects in the European regions; the experts of the fund provide technical expertise at any stage of the project cycle, from the early stages of the draft concept to the final application for EU financing. The work of the experts includes technical, economic and financial aspects of the project expertise [7].

JEREMIE (Joint European Resources for Micro to Medium Enterprises) cooperates with the European Commission and offers the EU Member States, through its representative offices, the possibility of using part of its EU Structural Funds to finance small and mediumsized enterprises (SMEs) through loans, microcredits, insurance, venture capital, business angels and guarantees [8].

\section{CONCLUSION}

Based on an analysis of existing approaches to cluster development in Germany, the following conclusion can be drawn: regional cluster policy is the art of integrating different interests, science, politics and management in a joint project. The cluster policy is aimed at supporting (existing or planned) regional clusters. This support is as follows:
- policy on the part of the national and federal governments, i.e. setting norms and rules in accordance with the law, competitive selection of pilot clusters and their subsequent support;

- developing and supporting cluster initiatives in line with the region's specialisation or supporting only clusters that have the potential to strengthen global leadership.

In general, the cluster policy is a real tool for promoting innovative technologies and is a promising approach for improving regional innovation opportunities.

Therefore, the national urban development policy brings together all concerned parties in addressing urban issues. This provides a basis for exchanging experience, discussing current problems and development trends, and facilitates the making of effective management decisions.

\section{References}

[1] T.N. Shilchenko Review of the main models of cluster-based policy of the state // Publisher: Taganrog Institute of Management and Economics (Taganrog). Taganrog Institute of Management and Economics Herald No. 1 (31). 2020.C. 22-27 ISSN: 2071-9604

[2] Projekte go-cluster Access: URL: https://www.clusterplattform.de/CLUSTER/ Navigation/DE/Bund/go-cluster/go-cluster.html

[3] Projekte der Spitzencluster-Wettbewerb - Mehr Innovation. Mehr Wachstum. Access: URL https://www.clusterplattform.de/CLUSTER/Navigation/DE/Bun $\mathrm{d} /$ SpitzenclusterWettbewerb/spitzencluster-wettbewerb.html

[4] Stadtentwicklungsbericht 2008. Neue urbane Lebens- und Handlungsräume. Herausgegeben vom Bundesministerium für Verkehr, Bau und Stadtentwicklung (BMVBS).Berlin, 2009. S.52

[5] Projekte der "Nationalen Stadtentwicklungspolitik". Access: URL: http://www.nationale-stadtentwicklungspolitik.de/cln_016 /nn_244664/DE/Projekte/ projekte_node.html?_nnn=true

[6] Technical assistance JESSICA. European Investment Bank Access: http://www.eib.org/products/technical_assistan/ce/jessica

[7] JASPERS (Joint Assistance to Support Projects in European Regions). Access: URL:http://www.jaspers-europa-info.org/

[8] European Investment Fund. Access: URL: http://www.eif.org/what_we_do/jeremie/index.htm 